NASA/TM-2010-216348

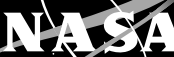

.

\title{
Thermal Properties of Lunar Regolith Simulants
}

Kenneth W. Street, Jr.

Glenn Research Center, Cleveland, Ohio

Chandra Ray

Missouri University of Science and Technology, Rolla, Missouri

Doug Rickman

Global Hydrology and Climate Center, Huntsville, Alabama

Daniel A. Scheiman

ASRC Aerospace Corporation, Cleveland, Ohio 


\section{NASA STI Program . . . in Profile}

Since its founding, NASA has been dedicated to the advancement of aeronautics and space science. The NASA Scientific and Technical Information (STI) program plays a key part in helping NASA maintain this important role.

The NASA STI Program operates under the auspices of the Agency Chief Information Officer. It collects, organizes, provides for archiving, and disseminates NASA's STI. The NASA STI program provides access to the NASA Aeronautics and Space Database and its public interface, the NASA Technical Reports Server, thus providing one of the largest collections of aeronautical and space science STI in the world. Results are published in both non-NASA channels and by NASA in the NASA STI Report Series, which includes the following report types:

- TECHNICAL PUBLICATION. Reports of completed research or a major significant phase of research that present the results of NASA programs and include extensive data or theoretical analysis. Includes compilations of significant scientific and technical data and information deemed to be of continuing reference value. NASA counterpart of peer-reviewed formal professional papers but has less stringent limitations on manuscript length and extent of graphic presentations.

- TECHNICAL MEMORANDUM. Scientific and technical findings that are preliminary or of specialized interest, e.g., quick release reports, working papers, and bibliographies that contain minimal annotation. Does not contain extensive analysis.

- CONTRACTOR REPORT. Scientific and technical findings by NASA-sponsored contractors and grantees.
- CONFERENCE PUBLICATION. Collected papers from scientific and technical conferences, symposia, seminars, or other meetings sponsored or cosponsored by NASA.

- SPECIAL PUBLICATION. Scientific, technical, or historical information from NASA programs, projects, and missions, often concerned with subjects having substantial public interest.

- TECHNICAL TRANSLATION. Englishlanguage translations of foreign scientific and technical material pertinent to NASA's mission.

Specialized services also include creating custom thesauri, building customized databases, organizing and publishing research results.

For more information about the NASA STI program, see the following:

- Access the NASA STI program home page at http://www.sti.nasa.gov

- E-mail your question via the Internet to help@ sti.nasa.gov

- Fax your question to the NASA STI Help Desk at $443-757-5803$

- Telephone the NASA STI Help Desk at 443-757-5802

- Write to: NASA Center for AeroSpace Information (CASI) 7115 Standard Drive Hanover, MD 21076-1320 
NASA/TM-2010-216348

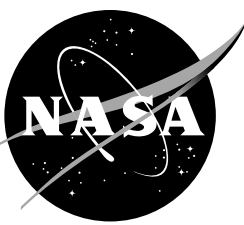

\section{Thermal Properties of Lunar Regolith Simulants}

Kenneth W. Street, Jr.

Glenn Research Center, Cleveland, Ohio

Chandra Ray

Missouri University of Science and Technology, Rolla, Missouri

Doug Rickman

Global Hydrology and Climate Center, Huntsville, Alabama

Daniel A. Scheiman

ASRC Aerospace Corporation, Cleveland, Ohio

Prepared for the

Earth and Space 2010 Conference

sponsored by the American Society of Civil Engineers

Honolulu, Hawaii, March 14-17, 2010

National Aeronautics and

Space Administration

Glenn Research Center

Cleveland, Ohio 44135 


\section{Acknowledgments}

The Stillwater Mining Company has provided very generous assistance and access to the rocks of the Stillwater Complex. The authors are grateful to William Betts for time spent on producing figures.

This report is a formal draft or working paper, intended to solicit comments and ideas from a technical peer group.

This report contains preliminary findings, subject to revision as analysis proceeds.

Trade names and trademarks are used in this report for identification only. Their usage does not constitute an official endorsement, either expressed or implied, by the National Aeronautics and Space Administration.

Level of Review: This material has been technically reviewed by technical management.

Available from

NASA Center for Aerospace Information 7115 Standard Drive

Hanover, MD 21076-1320
National Technical Information Service 5301 Shawnee Road Alexandria, VA 22312

Available electronically at http://gltrs.grc.nasa.gov 


\title{
Thermal Properties of Lunar Regolith Simulants
}

\author{
Kenneth W. Street, Jr. \\ National Aeronautics and Space Administration \\ Glenn Research Center \\ Cleveland, Ohio 44135 \\ Chandra Ray \\ Missouri University of Science and Technology \\ Rolla, Missouri 65409 \\ Doug Rickman \\ Global Hydrology and Climate Center \\ Huntsville, Alabama 35805 \\ Daniel A. Scheiman \\ ASRC Aerospace Corporation \\ Cleveland, Ohio 44135
}

\begin{abstract}
Various high temperature chemical processes have been developed to extract oxygen and metals from lunar regolith. These processes are tested using terrestrial analogues of the regolith. But all practical terrestrial analogs contain $\mathrm{H}_{2} \mathrm{O}$ and/or $\mathrm{OH}^{-}$, the presence of which has substantial impact on important system behaviors. We have undertaken studies of lunar regolith simulants to determine the limits of the simulants to validate key components for human survivability during sustained presence on the Moon. Differential Thermal Analysis (DTA) yields information on phase transitions and melting temperatures. Thermo-Gravimetric Analysis (TGA) with Fourier Transform Infrared (FTIR) analysis provides information on evolved gas species and their evolution temperature profiles. The DTA and TGA studies included JSC-1A fine (Johnson Space Center Mare Type 1A simulant), NU-LHT-2M (National Aeronautics and Space Administration (NASA) - United States Geological Survey (USGS) - Lunar Highlands Type 2M simulant) and its proposed feedstocks: anorthosite; dunite; high quality (HQ) glass and the norite from which HQ glass is produced. As an example, the DTA and TGA profiles for anorthosite follow. The DTA indicates exothermic transitions at 355 and $490{ }^{\circ} \mathrm{C}$ and endothermic transitions at 970 and $1235^{\circ} \mathrm{C}$. Below the $355^{\circ} \mathrm{C}$ transition, water is lost accounting for approximately 0.1 percent mass loss. Just above $490{ }^{\circ} \mathrm{C}$ a second type of water is lost, presumably bound in lattices of secondary minerals along with other volatile oxides. Limited TGA-FTIR data is available at the time of this writing. For JSC-1A fine, the TGA-FTIR indicates at least two kinds of water are evolved in the 100 to 500 and the 700 to $900{ }^{\circ} \mathrm{C}$ ranges. Evolution of carbon dioxide types occurs in the 250 to 545,545 to 705 , and 705 to $985^{\circ} \mathrm{C}$ ranges. Geologically, the results are consistent with the evolution of "water" in its several forms, $\mathrm{CO}_{2}$ from break down of secondary carbonates and magmatic, dissolved gas and glass recrystallization.
\end{abstract}

\section{Introduction}

The initial composition of the lunar crust is believed (Wilhelms, McCauley, and Trask, 1987; Jolliff, and Ryder, 2006; Heiken, Vaniman, and French, 1991) to have an average composition in the range of norite (Le Maitre, 2005). Volcanic eruptions, which followed deposited basaltic and other forms of materials as flows forming the mare (seas) of the Moon. The non-mare regions, termed the highlands and containing the original crustal materials, as well as a large portion of the mare have subsequently been destroyed by hypervelocity impacts producing a pervasive layer of shattered and altered residue. The 
resulting regolith covering the surface of the Moon primarily consists of this broken geologic material (Gary, McAfee, and Wolf, 1973) except for some outcrops in or around the mare. Therefore, the only resource available for human use from the Moon's surface will be from this regolith. A sustained presence on the Moon will require production of oxygen and water from these materials, either directly from the mineral fraction or from constituents entrained in the regolith, such as solar wind particles or cometary water.

As a resource, regolith contains substantial oxygen, on the order of 45 percent by weight, present in the mineral compositions, and trace hydrogen as a trapped volatile. Production of oxygen or water from the regolith will most likely involve high temperature processing. Hydrogen is readily released from glasses and minerals by thermal processing. Oxygen is readily recovered by reduction of feedstock materials with hydrogen (ilmenite reduction process) or carbon (carbothermal reduction processes). The recovered oxygen by carbothermal reduction would require a second reduction with hydrogen to produce water. All proposed methods do require the handling of large amounts of material to demonstrate technology suitable for use on the Moon (Stancati et al., 1991 and references therein). Due to the very limited availability of lunar regolith on Earth, all terrestrial demonstrations must be performed on lunar regolith simulants (hereafter referred to as simulants), which are composed of terrestrial analogues of lunar minerals, glasses, etc. Lunar water is extremely scarce but terrestrially it is ubiquitous. All terrestrial minerals have had substantial contact with water resulting in hydrothermal alteration, aqueous inclusions, and interstitial and adsorbed water. Consequently the thermal properties and water content of terrestrially made simulants are of great importance to the In-Situ Resources Utilization (ISRU) efforts to develop methods of manufacturing water on the Moon. One example is the testing of oxygen extraction using hydrogen reduction. Is the extracted water derived by release of oxygen from mineral structures or from the release of terrestrial water? Further, the sensitivity of the simulant materials to oxygen at elevated temperatures is also important. Any process which scavenges oxygen could be either detrimental or useful or both on the Moon.

Two recent, general-utility simulants have been developed by NASA. JSC-1A fine (referred to hereafter as JSC-1AF) is a mare simulant, whereas NU-LHT-2M is a prototype of a highland simulant. These simulants and constituents are described in the literature (Stoeser et al., 2008 and Rickman and Street 2008). The thermal properties of these materials and some of their constituents have been examined by Differential Thermal Analysis (DTA) and Thermo-Gravimetric Analysis (TGA) (Skoog, Holler and Nieman, 1997). DTA is a technique which measures small changes in temperature between a sample and an inert material as the temperature is raised providing information about phase transitions and chemical reactions. DTA also provides information regarding whether the changes are endothermic or exothermic. TGA is a technique which follows mass change upon heating of a sample providing information about the temperature where mass loss occurs. DTA and TGA data are herein reported for JSC-1AF, NU-LHT-2M and its component materials: anorthosite, dunite, HQ glass, and a norite used to manufacture the HQ glass.

\section{Experimental Section}

\section{Sample History}

JSC-1AF was procured from Orbitec, Madison, Wisconsin and used as provided. The feedstock used to make the simulant is a volcanic ash of basaltic composition from a cinder quarry in Merriam Crater $\left(35^{\circ} 20^{\prime} \mathrm{N}, 111^{\circ} 17^{\prime} \mathrm{W}\right)$, San Francisco Volcanic Field, near Flagstaff, Arizona.

The NU-LHT-2M was produced by the USGS, Denver, Colorado in close coordination with the Marshall Space Flight Center. It is a complex mixture consisting mainly of components either from or derived from the Stillwater Complex, which is a layered mafic intrusive system near Nye, Montana. The complex hosts a large platinum deposit mined by the Stillwater Mining Company. Anorthosite and norite were collected from the Stillwater Mine waste rock pile. The HQ glass, also referred to as Mill Sand Glass, was produced by Zybec, Advanced Products of Boulder, Colorado by melting the noritic "sand" 
waste from the Stillwater Mine's mill. A dunite from the Three Sisters olivine deposit in Washington State was purchased commercially by the USGS and provided for analysis courtesy of S. Wilson, USGS. Additional trace components were added, such as apatite, pyrite and synthetic beta tri-calcium phosphate, to replicate details of the regolith.

\section{Equipment}

The DTA experiments were performed in a Perkin Elmer, model DT-7, instrument (Norwalk, CT, USA) at a heating rate of $10{ }^{\circ} \mathrm{C} / \mathrm{min}$ in a flowing nitrogen gas $\left(30 \mathrm{~cm}^{3} / \mathrm{min}\right)$ using $60 \mathrm{~mm}^{3}$ internal volume high purity alumina $\left(\mathrm{Al}_{2} \mathrm{O}_{3}\right)$ crucible supplied by Perkin Elmer Corporation. A 99.999 percent pure alumina powder, also supplied by Perkin Elmer, was used as a reference material. About 3/4th of the crucible was filled with the sample with intermittent tapping for compaction. The mass of the samples ranged between 45 and $60 \mathrm{mg}$ depending upon density.

The TGA experiments were conducted in a NETZSCH, model STA 409, Thermal Analyzer at a heating rate of $10^{\circ} \mathrm{C} / \mathrm{min}$ in flowing nitrogen gas $\left(30 \mathrm{~cm}^{3} / \mathrm{min}\right)$ using $100 \mathrm{~mm}^{3}$ internal volume, high purity alumina crucible. A typical sample mass of $100 \mathrm{mg}$ was used for all the experiments.

The TGA-FTIR experiments were conducted using a TA Instruments TGA model 2950 interfaced with a Thermo Electron Nexus 470 FTIR via a heated stainless steel transfer line and heated gas cell with $\mathrm{KBr}$ windows. A heating rate of $10{ }^{\circ} \mathrm{C} / \mathrm{min}$ in flowing nitrogen gas $\left(20 \mathrm{~cm}^{3} / \mathrm{min}\right.$ and $40 \mathrm{~cm}^{3} / \mathrm{min}$ balance purge) was used. The transfer line and gas cell were kept at $240{ }^{\circ} \mathrm{C}$. Spectra were collected at a rate of 1 scan every $2 \mathrm{sec}$. A liquid nitrogen cooled mercury-cadmium-telluride (MCT) detector was used.

\section{Sample Specific Procedures}

The JSC-1AF, NU-LHT-2M and its components samples were run in both the TGA and the DTA. The JSC-1AF and NU-LHT-2M were run in duplicate. A JSC-1AF sample was also run in the DTA to $1050^{\circ} \mathrm{C}$ allowed to cool, and then rerun to $1250^{\circ} \mathrm{C}$.

\section{Results}

Results for TGA scans are found in Table 1 and Figures 1 to 3. The DTA profiles are summarized in Figures 1, 2, and 4.

TABLE 1.-SUMMARY OF DTA DATA FOR SAMPLES

\begin{tabular}{|c|c|c|c|c|c|c|c|}
\hline \multirow{2}{*}{$\begin{array}{r}\text { Sample } \\
\text { JSC-1AF } \\
\text { a }\end{array}$} & \multicolumn{7}{|c|}{$\begin{array}{l}\text { DTA transitions in order of appearance in }{ }^{\circ} \mathrm{C} \\
(\text { Ex }=\text { Exothermic; en = Endothermic })\end{array}$} \\
\hline & $325 \mathrm{Ex}$ & $723 \mathrm{Ex}$ & $849 \mathrm{Ex}$ & & & & \\
\hline JSC-1AF & --------- & --------- & --------- & 1130 en & 1170 en & 1210 en & \\
\hline NU-LHT-2M & $290 \mathrm{Ex}$ & $500 \mathrm{Ex}$ & $740 \mathrm{Ex}$ & $924 \mathrm{Ex}$ & $1048 \mathrm{Ex}$ & 1244 en & \\
\hline Anorthosite & $355 \mathrm{Ex}$ & $490 \mathrm{Ex}$ & 970 en & $\geqq 1235$ en & & & \\
\hline Dunite $^{c}$ & $310 \mathrm{Ex}$ & $>1350$ en & & & & & \\
\hline Norite & $425 \mathrm{Ex}$ & $455 \mathrm{Ex}$ & $488 \mathrm{Ex}$ & $>1225$ en & & & \\
\hline HQ Glass & $359 \mathrm{Ex}$ & $482 \mathrm{Ex}$ & 756 en & $934 \mathrm{Ex}$ & 1215 en & 1261 en & 1318 en \\
\hline
\end{tabular}

${ }^{\mathrm{a}} \mathrm{Run}$ to $1050{ }^{\circ} \mathrm{C}$

${ }^{\mathrm{b}}$ Rerun of sample previously run to $1050{ }^{\circ} \mathrm{C}$ and cooled

${ }^{\mathrm{c}}$ Profile is fairly featureless with weak transitions 


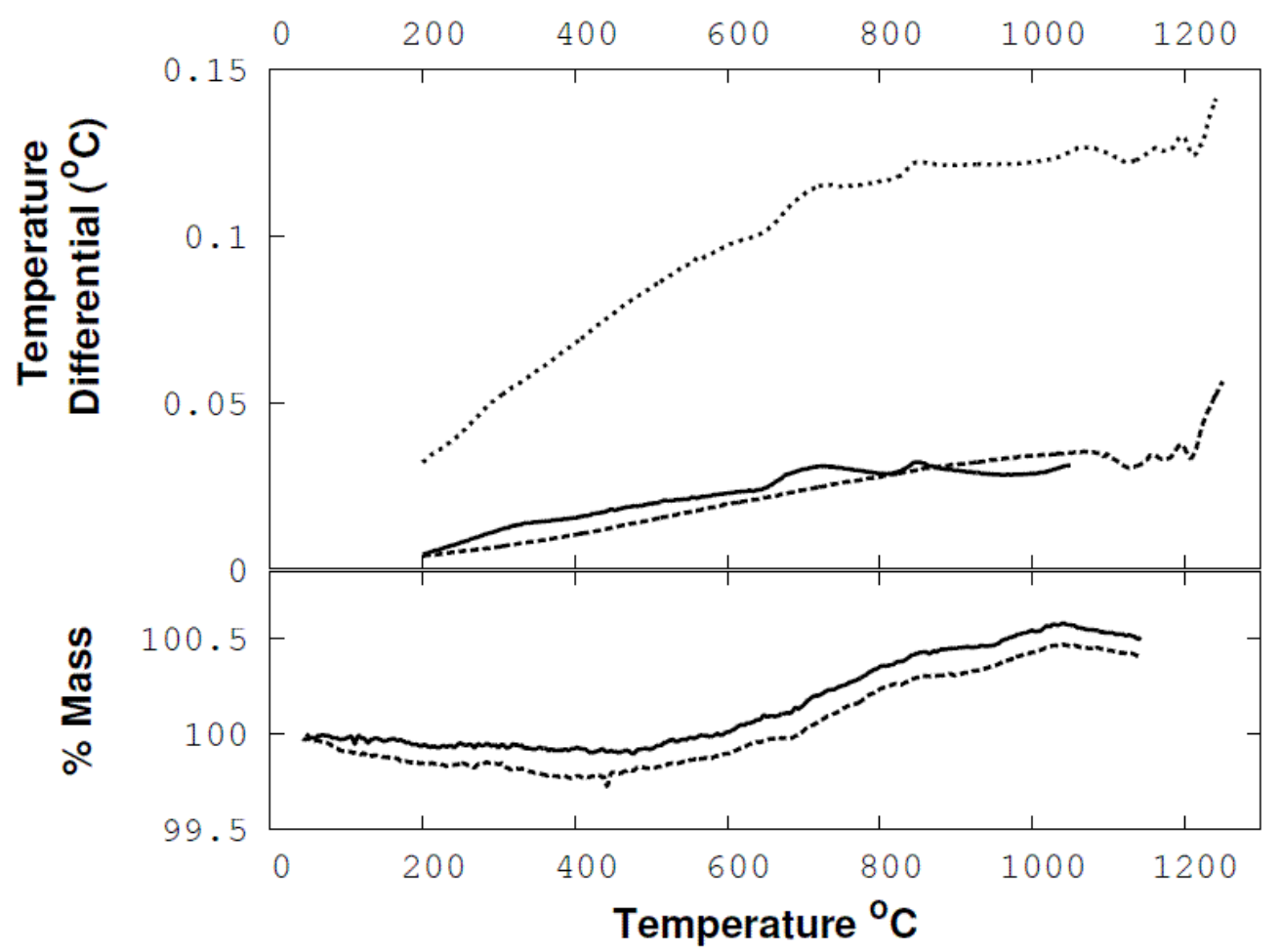

Figure 1.-DTA (top) and TGA (bottom) profiles for JSC-1AF. DTA to $1050^{\circ} \mathrm{C}(-)$ and rerun of same material after cooling (- - -). Duplicate DTA (․).). TGA of duplicate runs ( - and - - -).

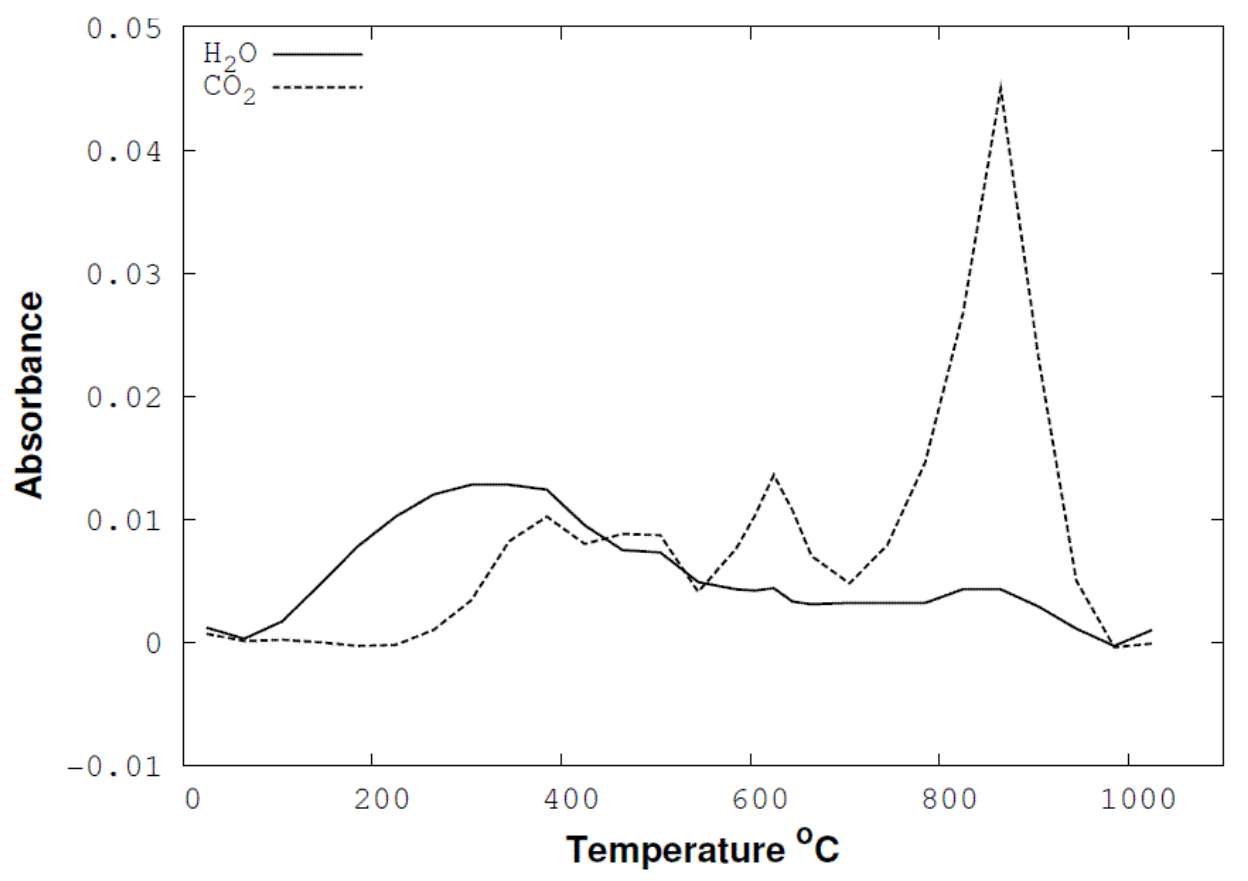

Figure 2.-TGA-FTIR profile of JSC-1AF. Water (-) and carbon dioxide (- . -) evolution profiles. 


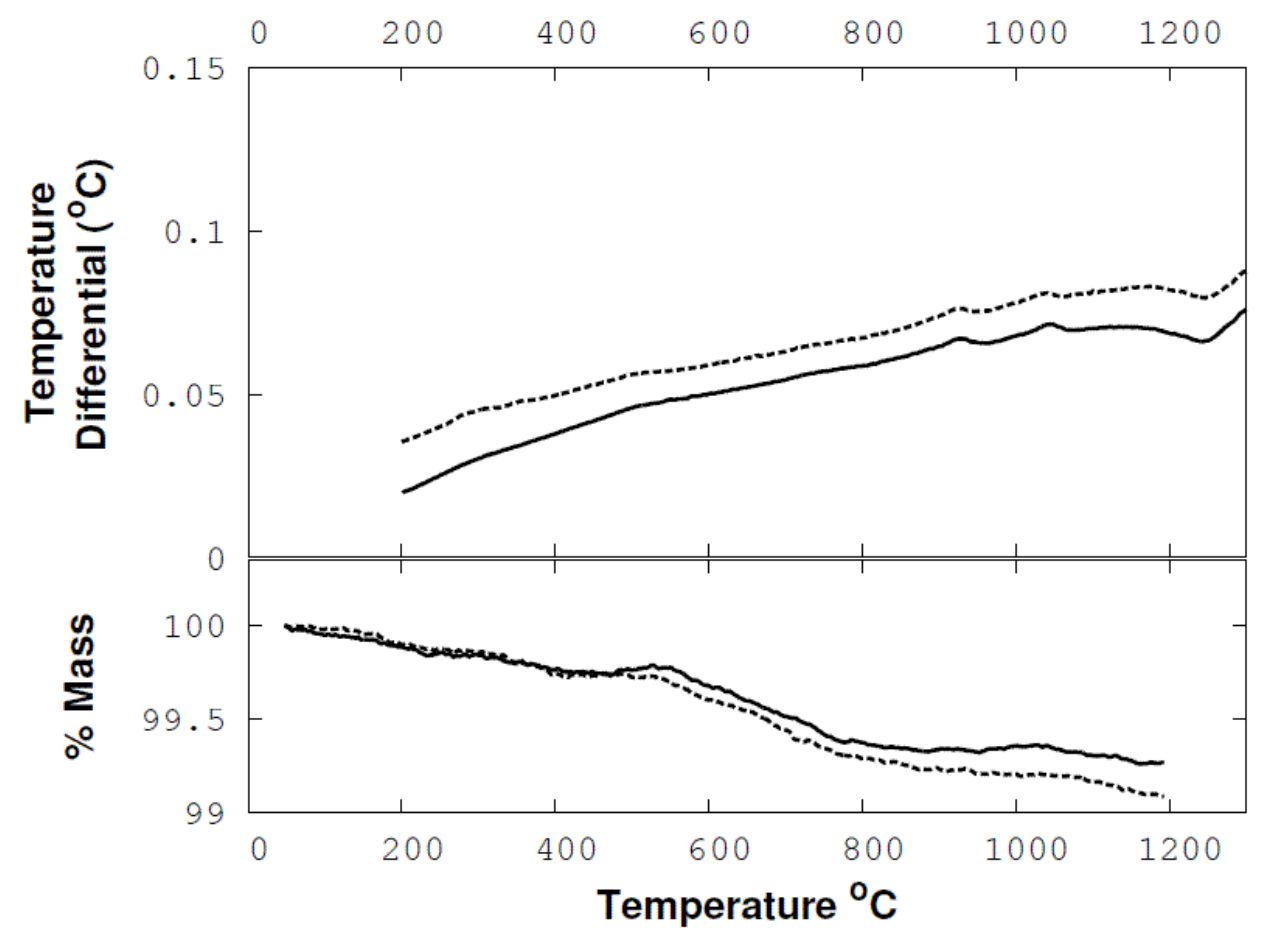

Figure 3.-Duplicate DTA (top) and TGA (bottom) profiles for NU-LHT-2M.

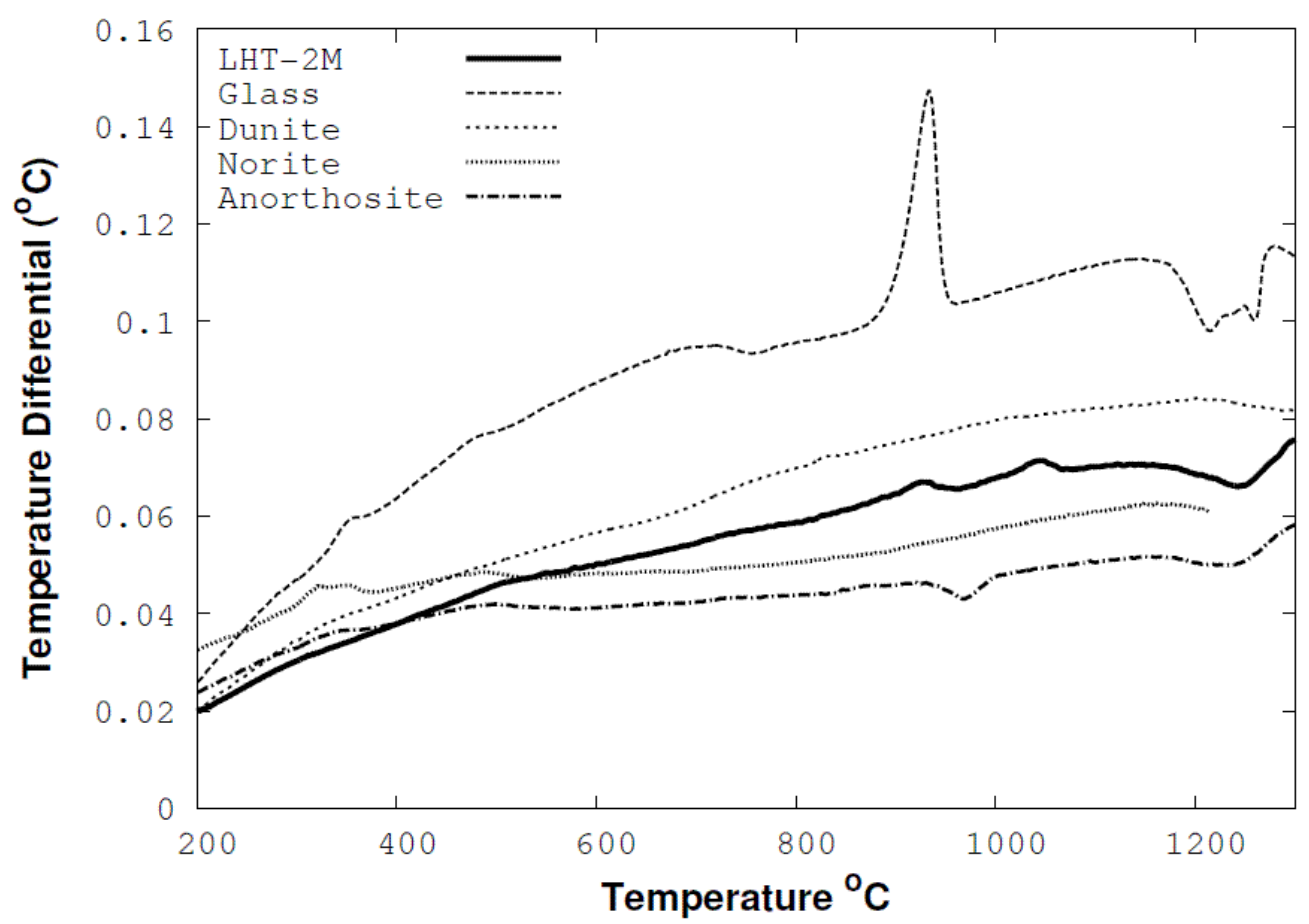

Figure 4.-DTA profiles for NU-LHT-2M (-) and constituent components: HQ glass (---),

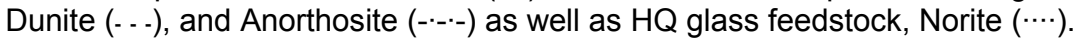




\section{Discussion}

\section{JSC-1AF}

JSC-1A (Johnson Space Center Lunar Simulant) is a lunar mare simulant designed to replicate the properties of lunar regolith sample 14163 (McKay et al., 1994). It is derived from basaltic volcanic ash. A volcanic ash is formed by the rapid, sometimes violent, exsolution of volatiles dissolved in the magma. Typical volatiles include $\mathrm{H}_{2} \mathrm{O}$ and $\mathrm{CO}_{2}$. The source ash is high in glass content (around 50 percent) and has substantial amounts of plagioclase $(37$ percent $)\left(\mathrm{Ca} /(\mathrm{Ca}+\mathrm{Na})=\sim \mathrm{An}_{70}\right)$ and lesser amounts of minerals such as olivine ( 9 percent) with traces of a number of other minerals $(<1$ percent each) (Carpenter, 2005; Taylor, 2005). The source material has been exposed to near-surface weathering conditions in an arid environment for approximately 150,000 years. This is sufficient time to begin development of caliche, which is a buildup of calcium carbonate.

The DTA of this simulant reveals exothermic events at 723 and $849{ }^{\circ} \mathrm{C}$, as seen in Figure 1, which could be due to crystallization of some of the glass present in the sample and/or phase transformation of existing compounds. The DTA pattern of the second run of the material previously heated to $1050{ }^{\circ} \mathrm{C}$ and allowed to cool, is featureless up to $1000{ }^{\circ} \mathrm{C}$, indicating all reactions that occurred within this temperature range in the first heating are irreversible. In Figure 1 the appearance of several endotherms occurring between 1100 and $1250{ }^{\circ} \mathrm{C}$ indicate melting events for multiple crystalline phases.

The FTIR data show evolution of two gases, $\mathrm{H}_{2} \mathrm{O}$ and $\mathrm{CO}_{2}$. The former originates from multiple sources. At temperatures between 100 to $300{ }^{\circ} \mathrm{C}$ we believe it is dominated by molecules bound to the surface of the mineral due to the polar nature of the water molecule. This bond is substantially stronger than the water-water bond. Additional water may be given off during dehydration reactions of secondary minerals developed during the weathering of the source volcanic ash, but the lack of distinct features in the DTA or TGA suggest the amounts present are relatively small. This is compatible with the care with which the source materials were hand-cobbed to remove apparent alteration. An alternative source may be $\mathrm{H}_{2} \mathrm{O}$ captured in the microcrystalline caliche, which is then liberated as the constituent calcium carbonate decomposes. Starting just above $300{ }^{\circ} \mathrm{C}$ the evolved $\mathrm{CO}_{2}$ is interpreted as coming from this breakdown. The first discharge, 300 to $550{ }^{\circ} \mathrm{C}$, may be due to amorphous carbonate material and the second, 550 to $700{ }^{\circ} \mathrm{C}$, due to crystalline carbonate materials. The $\mathrm{CO}_{2}$ evolution above $700{ }^{\circ} \mathrm{C}$ may be associated with the exothermic DTA transition at this temperature and is believed to be out-gassing of primary, magmatic $\mathrm{CO}_{2}$ trapped in the rapid chilling associated with the explosive formation of the ash. This interpretation is supported by the coevolution of $\mathrm{H}_{2} \mathrm{O}$, which would also be present in the same way.

The TGA data for JSC-1AF shows major gains in mass starting around $450{ }^{\circ} \mathrm{C}$. This is due to the oxidation of $\mathrm{Fe}^{++}$to $\mathrm{Fe}^{+++}$, which is a substantial component of the material in both minerals and presumably the glass. This reaction occurs at very low oxygen fugacity. Visually, this process is so intense that samples, which start as black, turn a rich, brick red. Having demonstrated the problem exists, interpretation of these data for JSC-1AF and the other materials become problematic and are not discussed further here.

The temperature of melting is very important for some engineering applications. Among other factors, for silicates melting temperatures are affected by the composition of the minerals, the presence of fluxing compounds, presence and abundance of volatiles, and the presence of disordered materials. All of these factors are probably functioning in the JSC-1 AF melting temperatures. The temperature of the melting for plagioclase is strongly dependent on its calcium content. Lower melting temperatures are associated with lower Ca levels in the plagioclase (Bowen, 1913). $\mathrm{An}_{70}$ is low compared to most lunar plagioclase. The apparent presence of small amounts of caliche probably acts as flux. The abundant glass will encourage melting, and the presence of entrapped $\mathrm{H}_{2} \mathrm{O}$ and $\mathrm{CO}_{2}$ will definitely affect melting. 


\section{NU-LHT-2M Components and Precursor Material}

The majority of the lunar surface is covered by highland type material. The samples from Apollo 16 serve as the model for properties of the Lunar Highland Type (LHT) series of simulants manufactured through a collaborative effort between NASA and the USGS (composing the NU- designation). For this study, in addition to the simulant material, several of the constituents were studied. This was done because the lunar regolith is essentially a suite of variations on four minerals: plagioclase, clino-pyroxene, orthopyroxene and olivine, plus glass made from these minerals. Thus, if the constituents are understood, the performance of any resulting mixture can be estimated. TGA-FTIR has not yet been run on these materials.

\section{Anorthosite}

Inspection of the DTA trace (Fig. 4) reveals that the behavior of the anorthosite has some differences and similarities to the prior JSC-1AF discussion. The DTA curve shows two minor exothermic transitions at 355 and $490{ }^{\circ} \mathrm{C}$ followed by a prominent endothermic transition at $970{ }^{\circ} \mathrm{C}$, these last two transitions being directly related to mass loss within the sample. There is known hydrothermal alteration in the Stillwater material. It is reasonable to interpret the 355 and 490 features as being associated with restructuring of the silicate lattices or carbonate destruction of these secondary minerals. Additional work has begun to characterize this mineral assemblage.

The feature at $970{ }^{\circ} \mathrm{C}$ could well be a melting of the residues created by the dewatering and degassing at the lower temperatures. It is unlikely melting at this low of a temperature is associated with reactions involving the high calcium plagioclase ( $\sim \mathrm{An}_{79}$, Stoeser et al., 2008) which makes up 90 percent + of this sample. Sintering of the plagioclase may have begun near the end of the run, above $1200^{\circ} \mathrm{C}$. As these reactions are substantially below the predicted melting temperature for the plagioclase or the very minor pyroxene contamination, it must be caused by some other factor. It is hypothesized that the disordered silicates or even carbonates left by the exothermic reactions at the lower temperatures are melting and acting as a flux.

\section{Dunite}

The dunite, which is essentially pure olivine, is a highly refractory material and is relatively free of secondary minerals derived from either weather or hydrothermal activity. Thus, as expected, the DTA shows no significant features over this temperature range.

\section{Norite}

The DTA profile for the norite essentially parallels the anorthosite as it is from the same geologic environment and contains $\sim 70$ percent high calcium plagioclase ( $\sim \mathrm{An}_{87}$, Stoeser et al., 2008). Essentially all the comments made for the anorthosite sample apply to the norite.

\section{HQ Glass}

This glass exhibits a sharp and significant exothermic transition at $934{ }^{\circ} \mathrm{C}$ in the DTA. This is attributed to crystallization. The contrast between the HQ glass and the norite and anorthosite illustrate the importance of glass being present or absent in terms of thermal performance of the simulant or regolith (Fig. 4).

\section{NU-LHT-2M}

The interpretation of the DTA for this simulant should closely resemble the sum of the mass-weighted DTA curves for the major components as presented above. Due to the extreme glass content the exothermic peak at $934{ }^{\circ} \mathrm{C}$ for the glass is also observed at $924{ }^{\circ} \mathrm{C}$ in the simulant. The $1048{ }^{\circ} \mathrm{C}$ peak in 
the stimulant is also prominent and unexplained from the other components examined in this study, leading to the hypothesis that a minor constituent not examined herein must have an extremely exothermic transition at this temperature. Because of the large number of poorly overlapping transitions of the constituents, it is difficult to uniquely identify and assign transitions in the simulant. In fact, some of the peaks may appear to have shifted for this reason. A good example is the $10^{\circ} \mathrm{C}$ shift in the aforementioned glass exotherm. The endothermic event at $1244^{\circ} \mathrm{C}$ is attributed to partial melting of the sample and corresponds to the melting temperature of the HQ glass. There are undoubtedly more melting events above $1300{ }^{\circ} \mathrm{C}$, the maximum temperature of the DTA instrument.

The TGA on the other hand has so little mass loss that the minor constituents cannot be ignored. For example, the pyrite readily decomposes with oxygen and heat to iron oxide and sulfur oxides. Compounding the problem is the mass gain, which is presumably due to the oxidation of $\mathrm{Fe}^{2+}$ to $\mathrm{Fe}^{3+}$ in various constituent phases. The amount of this oxidation is small enough that upon heating, it barely discolors the material, in contrast to JSC-1AF. The mass loss below $500{ }^{\circ} \mathrm{C}$ is attributable dominantly to water and possible evolution of $\mathrm{CO}_{2}$ from the breakdown of carbonate minerals, both associated with hydrothermal alteration.

\section{Conclusions}

The study of water and other contaminants in simulants is of great importance to the simulant user community, especially those involved in the processing of material. The simulant materials are shown to evolve both $\mathrm{H}_{2} \mathrm{O}$ and $\mathrm{CO}_{2}$ at multiple temperatures and in amounts specific to each. As these do not match expected performance of lunar regolith, there can be misleading effects occurring during the engineering tests. Significant differences between regolith and simulant will provide false operational information and may lead to equipment that will not meet the intended function on the Moon. Specific concerns include: (a) Applications where temperatures are elevated. (b) Behavior differences when testing in vacuum. (c) Evolution of spurious volatiles under test conditions can be a significant concern. In this study we have begun to characterize important differences that will be crucial to equipment developers. It is apparent from the above discussion that significant follow-on work is required. These include (1) Acquiring DTA and TGA data where oxygen is excluded from the measurements; (2) Determining the thermal properties of other constituents of simulants; and (3) Development of routine procedures that can be employed in the quality control for the production of simulants.

\section{References}

Bowen, N.L. (1913) "The melting phenomena of the plagioclase feldspars," Am. J.Sci., 4 (35), 577-599. Carpenter, P. (2005) "Characterization strategies and requirements for lunar regolith simulant materials," Lunar Regolith Simulant Materials: Recommendations for Standardization, Production, and Usage, Huntsville, Alabama. http://isru.msfc.nasa.gov/lib/Documents/wksp2005/day1/ Carpenter.pdf (Nov 18, 2009).

Gary, M., McAfee, R., and Wolf, C.L., (1973) "Glossary of geology," American Geological Institute, Washington, D.C.

Heiken, G., Vaniman, D., and French, B.M., (1991) Lunar sourcebook: A user's guide to the Moon. Cambridge University Press, Cambridge, U.K.

Jolliff, B.L., Wieczorek M.A., Shearer C.K., and Neal C.R., (2006) "New views of the Moon," Reviews in Mineralogy and Geochemistry," 60, MSA, Chantilly, Virginia.

Le Maitre, R.W. and International Union of Geological Sciences. (2005) Subcommission on the Systematics of Igneous Rocks., Igneous Rocks: A Classification and Glossary of Terms: Recommendations of the International Union of Geological Sciences, Subcommission on the Systematics of Igneous Rocks, 2nd ed. Cambridge University Press, Cambridge, U.K.

McKay, D.S., Carter, J.L., Boles, W.W., Allen, C.C., and Allton, J.H. (1994) "JSC-1: a new lunar soil stimulant," Engineering, construction, and operations in space IV, ASCE, 857-866. 
Rickman, D., and Street, K.W. (2008) "Expected Mechanical Characteristics of Lunar Dust: A Geological View," Proceedings of the Space Technology and Applications International Forum, Albuquerque, NM. AIP Conf. Proc., 969, 949-955.

Skoog, D.A, Holler, J.F., and Nieman, T.A. (1997) "Chapter 31 Thermal methods," Principles of instrumental analysis, 5th ed., Saunders College Publishing or Harcourt Brace College Publishers.

Stancati, M.L., Jacobs, M.K., Cole, K.J., and Collins, J.T. (1991) "In situ propellant production: Alternatives for mars exploration," NASA-CR-187192, 29-55.

Stoeser, D., Wilson, S., Weinstein, M., Rickman, D., Lower, H., Meeker, G., Schrader, C., McLemore, C., and Fikes, J. (2008) "The LHT (Lunar Highlands Type) regolith simulant series," National Geological Society of America Conference, Houston, Texas.

Taylor, L.A. (2005) "JSC-1A "Exposed" Petrography, Mineralogy, and Geochemistry," 2005-Planetary Geosciences Institute, The University of Tennessee, Knoxville, Tennessee.

Wilhelms, D.E., McCauley, J.F., and Trask, N.J. (1987) "The geologic history of the Moon," U.S. Geological Survey professional paper 1348, U.S.G.S., Dept. of the Interior, Washington D.C. 


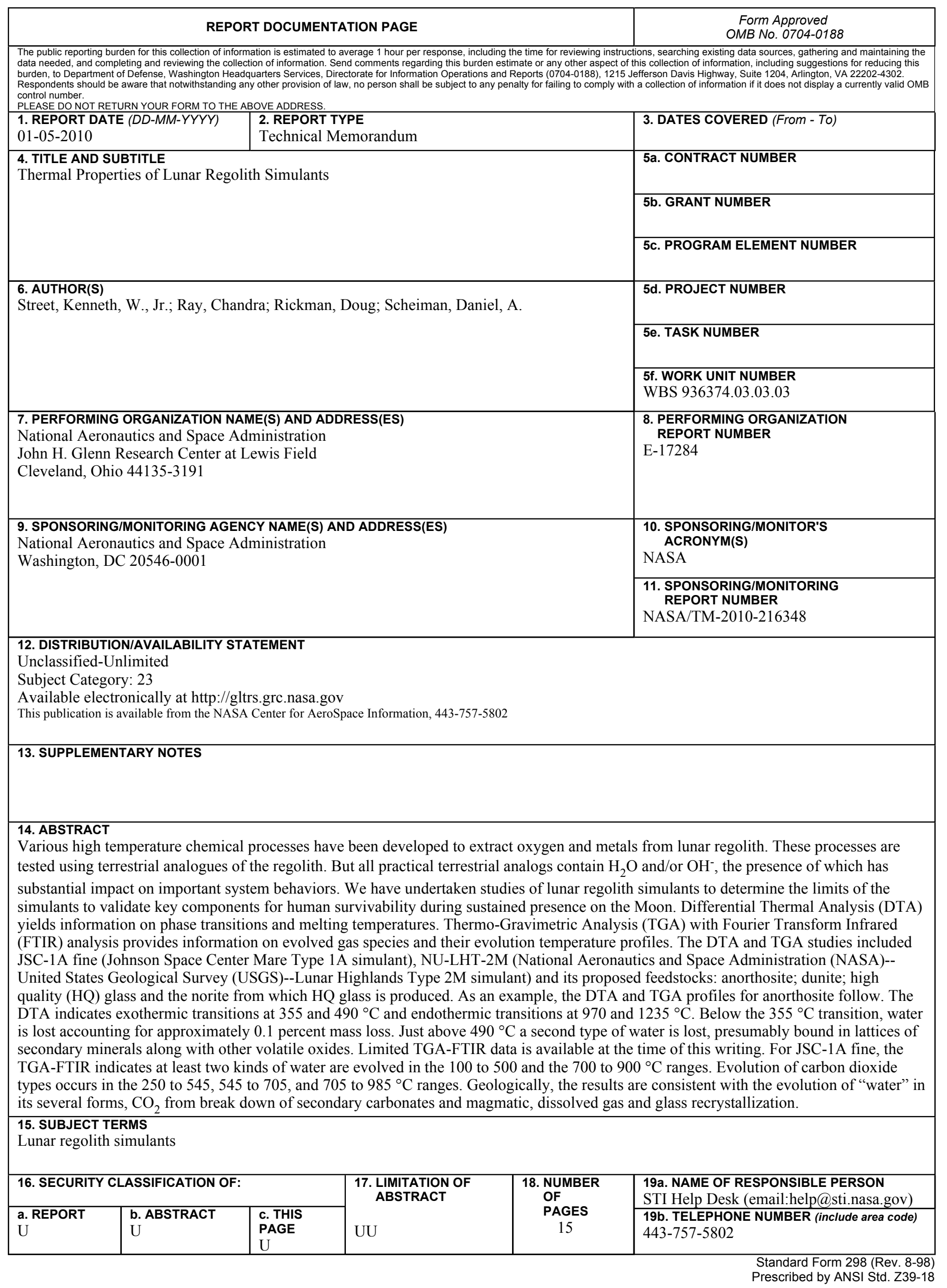



